\title{
Sepsis-3 - ny definisjon med bismak?
}

\author{
I den nye sepsisdefinisjonen vektlegges infeksjonsutløst organdysfunksjon. Den nye definisjonen er mer \\ presis enn den gamle. Men det er ved å forebygge organsvikt vi oppnår best overlevelse hos pasienter med \\ alvorlige infeksjoner.
}

\section{To SIRS-kriterier? Det fär man av å løpe etter bussen.}

Utsagnet får stå som illustrasjon på en nokså utbredt holdning til den internasjonale sepsisdefinisjonen vi har hatt siden 1992 (1). Den favnet for vidt til å være klinisk anvendelig og fremsto samtidig som begrensende - pasienter med infeksjon og organsvikt, men uten to eller flere SIRS-kriterier, falt utenfor sepsisdefinisjonen. Definisjonen manglet både spesifisitet og sensitivitet (2).

Det kom derfor ikke som noen overraskelse da JAMA i februar 2016 publiserte The Third International Consensus Definitions for Sepsis and Septic Shock (Sepsis-3) (3). Dette arbeidet ble initiert av det amerikanske Society for Critical Care Medicine (SCCM) og European Society of Intensive Care Medicine (ESICM). Disse organisasjonene utpekte hver sin representant, som i sin tur rekrutterte ledende sepsisforskere til arbeidet. Det er 19 mannlige, vestlige medforfattere av konsensusdokumentet. Ingen kvinner, pasientgrupperinger, myndighetsrepresentanter eller andre interessenter har vært representert i gruppen. Det var heller ingen representanter fra fattige land (der sepsis tar flest liv) blant forfatterne (4). JAMA har så langt refusert debattinnlegg som kritiserer dette.
De gamle sepsiskriteriene omfattet pasienter med alvorlige infeksjoner, men organdysfunksjon var ingen absolutt forutsetning. Nå defineres sepsis som «livstruende organsvikt som følge av dysregulert vertsrespons mot infeksjon». Dette manifesterer seg som en akutt endring i SOFA-skår på $\geq 2$ poeng og assosiert mortalitetsrate på $10 \%$ eller mer (5).

SOFA-skår (Sequential Organ Failure Assessment) gir en enkel samleskår av seks

\section{«Ville den nye sepsis- definisjonen ha sett annerledes ut dersom sepsispanelet hadde hatt en bredere sam- mensetning?»}

organsystemer (respirasjon, sirkulasjon, koagulasjon, lever, nyrer, sentralnervøs respons). Skåringen gjøres daglig, slik at pasientens tilstand kan følges over tid. Skåren ble primært utviklet for sepsispasienter,

Tabell 1 Sepsis - gamle og nye kriterier

\section{Klinisk mistanke om eller bekreftet infeksjon +}

Gammel definisjon Systemic inflammatory response syndrome (SIRS) (1)

Sepsis $\quad \geq 2$ SIRS-kriterier Itemperatur, respirasjonsfrekvens, hjertefrekvens, leukocytose /-penil

Alvorlig sepsis Organsvikt

Septisk sjokk Sirkulasjonssvikt

Ny definisjon Sepsis-3 (3)

Sepsis ${ }^{1} \quad \Delta \geq 2$ SOFA-poeng ${ }^{2}(5)$

Klinisk skår: $\geq 2$ qSOFA (Ikke tilstrekkelig for å stille diagnosen sepsis, kun indikator]

Septisk sjokk Behov for vasoaktive legemidler for å opprettholde middelarterietrykk $>65$ $\mathrm{mm} \mathrm{Hg}$, og s-laktat $>2,0 \mathrm{mmol} / \mathrm{l}$ til tross for adekvat væskebehandling

Den nye definisjonen skiller ikke «sepsis» fra «alvorlig sepsis«

Elementer som inngår i Sequential Organ Failure Assessment (SOFA-skår)

- $\mathrm{PaO}_{2}-\mathrm{FiO}_{2}$-ratio

- Glasgow Coma-skår (GCS)

- Middelarterietrykk eller vasopressordoser

- Bilirubin

- Trombocytter

- Kreatinin eller døgndiurese

${ }^{3}$ Quick SOFA: Takypné ( $\geq 22 / \mathrm{min}$ ), endret mental status, hypotensjon (systolisk blodtrykk $\leq 100 \mathrm{~mm} \mathrm{Hg}$ ) men er senere validert til også å gjelde andre typer intensivpasienter (6).

Det er også blitt introdusert et klinisk screeninginstrument, quick-SOFA (qSOFA), med enkle indikatorer på alvorlig sykdom (tab 1) $(1,3,5)$. Dette retter opp svakhetene ved den forrige definisjonen, som omfattet for mange pasienter uten alvorlig sykdom. Det har også vist seg at en stor del av dem med infeksjonsutløst organsvikt ikke ble fanget opp av SIRS-kriteriene (2). De nye kriteriene skaper imidlertid sine egne utfordringer:

Sepsis er etter dette en tilstand med svært høy dødelighet: Pasienter som oppfyller kriteriene for sepsis vil ha en dødelighet på $>10 \%$ (3), og ved septisk sjokk er dødeligheten $>30 \%$ (7). Den nye definisjonen vil med nødvendighet påvirke tenkemåten til klinikere verden over og har potensielt innflytelse på vår evne til å gjenkjenne kliniske tegn på alvorlige infeksjoner. Uten tvil vil en ny definisjon også skape et skille - de som oppfyller de nye sepsiskriteriene vil bli oppfattet som sykere enn de som faller utenfor definisjonen.

Dette har sine fordeler. Det er blitt tydeligere at sepsis er en tilstand som skal behandles i intensivavdeling. Men det er én alvorlig ulempe: Pasienter med alvorlige infeksjoner, men som fortsatt ikke har utviklet organsvikt, er kanskje den gruppen som har aller mest å hente på rask intervensjon (antibiotikabehandling, ev. kirurgi, væske og annen støttende behandling). Ved etablert organsvikt er nemlig dødeligheten høy selv ved rask intervensjon og god kvalitet på behandlingen (8). Det er ved å forebygge organsvikt vi oppnår best overlevelse. Det er derfor uheldig dersom slike pasienter heretter blir vist mindre aktpågivenhet fordi de ikke omfattes av sepsisbegrepet.

Den nye definisjonen har fått kritikk som gjenspeiler innholdet i denne kommentarartikkelen $(9,10)$. Ville den nye sepsisdefinisjonen ha sett annerledes ut dersom sepsispanelet hadde hatt en bredere sammensetning? Det er det umulig å svare på i dag, men vi vet at sepsis er en av de viktigste årsakene til svangerskapsrelaterte dødsfall i den tredje verden (11) og at lungebetennelse med tilhørende respirasjonssvikt er den viktigste årsak til barnedødelighet i fattige land (12). Dette er pasienter som kan se langt etter behandling $i$ en moderne intensivavdeling. Den eneste sjansen de har, er å få behandling før de har utviklet manifest organsvikt og dermed blir omfattet av Sepsis-3-kriteriene. 
Forfatterne bak den nye definisjonen har gang på gang understreket at Sepsis-3 verken er en diagnose eller representerer en terskel for tiltak. Alle pasienter har et selvsagt krav på undersøkelse og behandling ut fra aktuell klinisk tilstand. Det gjenstår imidlertid å se hvordan klinikere verden over vil agere når ny sepsisdefinisjon tas $\mathrm{i}$ bruk, herunder hvordan behandlingen av dem som ikke omfattes av kriteriene vil utvikle seg.

\section{Jon Henrik Laake}

jlaake@ous-hf.no

Jon Henrik Laake (f. 1963) er spesialist i anestesiologi, med spesialkompetanse i hjerteanestesiologi og intensivmedisin. Han er overlege ved Akuttklinikken, Oslo universitetssykehus, Rikshospitalet, og leder av Clinical Practice Committee i Scandinavian Society of Anaesthesiology and Intensive Care Medicine (SSAI). Forfatter har fylt ut ICMJE-skjemaet og oppgir ingen interessekonflikter.

\section{Litteratur}

1. Bone RC, Balk RA, Cerra FB et al. Definitions for sepsis and organ failure and guidelines for the use of innovative therapies in sepsis. Chest 1992; 101: 1644-55

2. Kaukonen K-M, Bailey M, Pilcher D et al. Systemic inflammatory response syndrome criteria in defining severe sepsis. N Engl J Med 2015; 372: 1629-38.

3. Singer M, Deutschman CS, Seymour CW et al. The Third International Consensus Definitions for Sepsis and Septic Shock (Sepsis-3). JAMA 2016; 315: $801-10$.

4. Vincent J-L, Marshall JC, Namendys-Silva SA et al. Assessment of the worldwide burden of critical illness: the intensive care over nations (ICON) audit. Lancet Respir Med 2014: 2: 380-6.

5. Vincent JL, Moreno R, Takala J et al. The SOFA (Sepsis-related Organ Failure Assessment) score to describe organ dysfunction/failure. On behalf of the Working Group on Sepsis-Related Problems of the European Society of Intensive Care Medicine. Intensive Care Med 1996; 22: 707-10.

6. Vincent JL, de Mendonça A, Cantraine F et al. Use of the SOFA score to assess the incidence of organ dysfunction/failure in intensive care units: results of a multicenter, prospective study. Working group on «sepsis-related problems» of the European Society of Intensive Care Medicine. Crit Care Med 1998; 26: 1793-800.

7. Shankar-Hari M, Phillips GS, Levy ML et al. Developing a New Definition and Assessing New Clinical Criteria for Septic Shock: For the Third International Consensus Definitions for Sepsis and Septic Shock (Sepsis-3). JAMA 2016: 315: 775-87.
8. Angus DC, van der Poll T. Severe sepsis and septic shock. N Engl J Med 2013: 369: 2063.

9. Simpson SQ. New Sepsis Criteria: A Change We Should Not Make. Chest 2016; 149: 1117-8.

10. Cortés-Puch I, Hartog CS. Change is Not Neces sarily Progress: Revision of the Sepsis Definition Should Be Based on New Scientific Insights. Am J Respir Crit Care Med 2016. E-publisert 11.5.2016.

11. Say L, Chou D, Gemmill A et al. Global causes of maternal death: a WHO systematic analysis. Lancet Glob Health 2014: 2: e323-33.

12. Izadnegahdar R, Cohen AL, Klugman KP et al. Childhood pneumonia in developing countries. Lancet Respir Med 2013; 1: 574-84.

Mottatt 2.5. 2016, første revisjon innsendt 27.5. 2016, godkjent 30.5. 2016. Redaktør: Liv-Ellen Vangsnes.

Publisert først på nett. 